\title{
Fall Armyworm-Associated Gut Bacteria Modulate Plant Defense Responses
}

\author{
Flor E. Acevedo, ${ }^{1}$ Michelle Peiffer, ${ }^{1}$ Ching-Wen Tan, ${ }^{1}$ Bruce A. Stanley, ${ }^{2}$ Anne Stanley, ${ }^{2}$ Jie Wang, ${ }^{1,3}$ \\ Asher G. Jones, ${ }^{1}$ Kelli Hoover, ${ }^{1}$ Cristina Rosa, ${ }^{4}$ Dawn Luthe, ${ }^{5}$ and Gary Felton ${ }^{1}$ \\ ${ }^{1}$ Department of Entomology, The Pennsylvania State University, 501 Agricultural Sciences and Industries Building, University \\ Park, 16802, U.S.A.; ${ }^{2}$ Section of Research Resources, The Pennsylvania State University College of Medicine, 500 University \\ Drive, Hershey, 17033 , U.S.A.; ${ }^{3}$ Department of Ecology, South China Agricultural University, Guangzhou, Guangdong 510640, \\ China; ${ }^{4}$ Department of Plant Pathology, The Pennsylvania State University, 321 Buckhout Lab; and ${ }^{5}$ Department of Plant \\ Science, The Pennsylvania State University, 216 Agricultural Sciences and Industries Building
}

Accepted 29 August 2016.

\begin{abstract}
Mechanical damage caused by insect feeding along with components present in insect saliva and oral secretions are known to induce jasmonic acid-mediated defense responses in plants. This study investigated the effects of bacteria from oral secretions of the fall armyworm Spodoptera frugiperda on herbivore-induced defenses in tomato and maize plants. Using culture-dependent methods, we identified seven different bacterial isolates belonging to the family Enterobacteriacea from the oral secretions of field-collected caterpillars. Two isolates, Pantoea ananatis and Enterobacteriaceae-1, downregulated the activity of the plant defensive proteins polyphenol oxidase and trypsin proteinase inhibitors (trypsin PI) but upregulated peroxidase (POX) activity in tomato. A Raoultella sp. and a Klebsiella sp. downregulated POX but upregulated trypsin PI in this plant species. Conversely, all of these bacterial isolates upregulated the expression of the herbivore-induced maize proteinase inhibitor (mpi) gene in maize. Plant treatment with $P$. ananatis and Enterobacteriaceae-1 enhanced caterpillar growth on tomato but diminished their growth on maize plants. Our results highlight the importance of herbivore-associated microbes and their ability to mediate insect plant interactions differently in host plants fed on by the same herbivore.
\end{abstract}

Physical damage caused by feeding of chewing insects induces jasmonic acid (JA)-mediated defense responses in plants. The magnitude of these responses is often modified by insectderived cues present in their saliva, oral secretions, and frass (Acevedo et al. 2015; Ray et al. 2015). The saliva of lepidopteran larvae is mainly produced by the labial salivary glands and released extraorally through the spinneret (Felton et al. 2014). Some proteins present in caterpillar saliva can directly interact with plants to enhance or suppress

Nucleotide sequence data is available in the GenBank database under accession numbers KX161909 through KX161924.

Corresponding author: Gary W. Felton; E-mail: gwf10@psu.edu; Telephone: +1.814 .863 .7789 .

*The $e$-Xtra logo stands for "electronic extra" and indicates that six supplementary figures, one supplementary table, and supplementary methods are published online.

C 2017 The American Phytopathological Society herbivore-induced defenses. Previous studies have shown that glucose oxidase (GOX) (Musser et al. 2002; Tian et al. 2012), adenosine triphosphatases (Wu et al. 2012), and a recently identified phospholipase C (PLC) (M. Peiffer, F. E. Acevedo, S. Ray, L. Rivera-Vega, D. S. Luthe, and G. W. Felton unpublished) modulate JA-mediated defense responses in several host plants. Different from saliva, oral secretions or regurgitant arise from an insect's foregut (Grant 2006) and contain fatty acid amino acid conjugates, insect- and plant-derived enzymes, and microbes that modulate defense responses in plants (Chung et al. 2013; Schmelz 2015). Insect frass contains plant proteins, insect-derived proteins, and microbes that regulate plant defenses (Ray et al. 2016). A large volume of work has been dedicated to the identification of elicitors and effectors (molecules that modulate plant defenses) present in insect saliva and oral secretions, but there is very little known about the effects of herbivore-associated microbes on regulation of plant defenses.

Insects harbor diverse microbial communities that influence their interaction with other trophic levels and their environment. Some known services provided by insect-associated microorganisms include nutrient provisioning, synthesis of pheromone components, regulation of insect-immune responses, and protection against parasites (Douglas 2015; Engel and Moran 2013). Microbes are essential for plant-feeding insects whose diet is generally either low in nutrients, high in chemical defenses, or both. Symbionts associated with phytophagous insects provide essential amino acids (Douglas 2015), aid in digestion (Visôtto et al. 2009), and detoxify plant secondary metabolites such as terpenes and phenolics (Hammer and Bowers 2015). For instance, the phytophagous gypsy moth Lymantria dispar harbors symbiotic bacteria of the genus Acinetobacter that appear to metabolize toxic phenolic glycosides from its host plant Populus tremuloides (Mason et al. 2016). In other cases, association with specific microbes influences the ability of insects to utilize specific host plants; for example, fecundity of the pea aphid Acyrthosiphon pisum on white clover is highly dependent on the presence of the endosymbiont "pea aphid U-type" (Tsuchida et al. 2004). Similarly, the stinkbug Megacopta punctatissima owes its ability to use legume crops to the associated symbiont Ishikawaella capsulate (Hosokawa et al. 2007). Therefore, the capability of some phytophagous insects to exploit particular host plants seems to be, at least in part, mediated by their association with specific microorganisms. 
Besides aiding in nutrition and detoxification, microorganisms associated with plant-feeding insects can also regulate induced plant defenses. This regulation can be indirect, by affecting herbivore physiology or behavior, which can, in turn, modify their perception by plants (Zhu et al. 2014). Alternatively, microbes present in insect oral secretions come into direct contact with plant wounds during insect feeding. Upon recognition of microbe-derived molecules, plants activate defensive pathways that can further affect the fitness of their herbivore host (Zhu et al. 2014). For example, the Colorado potato beetle Leptinotarsa decemlineata harbors gut endosymbiotic bacteria that, when deposited on plants through its oral secretions, downregulate JA-induced defenses in tomato. Hosting these bacteria seems to be beneficial for the beetle, because downregulation of JA-related defenses increased insect performance (Chung et al. 2013). Beetles do not possess salivary glands. Therefore, their oral secretions mainly arise from their gut as regurgitant. Lepidopteran larvae, on the other hand, release secretions from both their salivary glands (saliva) and from their gut (as regurgitant) to different degrees (Felton et al. 2014). Much work has been done to characterize molecules present in the lepidopteran oral secretions that regulate induction of plant defenses, while neglecting the role that microbes may play in these interactions (Felton and Tumlinson 2008).

Lepidopterans constitute one of the largest phytophagous insect groups, comprising about 180,000 described species, some of which are important agricultural pests (The Lepidoptera Taxome Project). Surprisingly, studies of their gut microbiome are scarce, comprising only a few species, including Pieris rapae (Robinson et al. 2010), Spodoptera littoralis (Tang et al. 2012), Helicoverpa armigera (Priya et al. 2012) Spodoptera exigua (Ping et al. 2007), Anticarsia gemmatalis (Visôtto et al. 2009), Plutella xylostella (Indiragandhi et al. 2008), and Lymantria dispar (Broderick et al. 2004). Gut-associated bacteria of lepidopterans can promote plant growth (Indiragandhi et al. 2008), produce digestive proteases (Visôtto et al. 2009), metabolize toxic plant compounds (Mason et al. 2016), and appear to help in the hydrolysis or synthesis of $\mathrm{N}$-acyl amino acid conjugates, which are elicitors of JA-mediated plant defenses (Ping et al. 2007). These studies suggest a potential role of gut microbes in plant utilization and plant defense regulation in lepidopteran, which has not been explored thus far.

In this study, we investigated the effects of bacteria isolated from the oral secretions of the polyphagous herbivore fall armyworm (FAW) Spodoptera frugiperda (Lepidoptera: Noctuidae) on herbivore-induced defenses in two host plants, tomato and maize. We used culture-dependent methods to identify microbes associated with field-collected FAW caterpillars and tested the direct effect of these bacteria isolates on plant JA-mediated defense responses. We also tested the indirect effect of some of these isolates on activity and relative abundance of insect salivary proteins.

\section{RESULTS}

\section{Identification of FAW-associated gut bacteria and their effect on herbivore-induced defenses in tomato and maize plants.}

We tested the effect of FAW caterpillar gut bacteria on JAmediated plant defenses in tomato and maize plants, following the procedures reported by Chung et al. (2013), with some modifications. Field-collected caterpillars were either pretreated with antibiotics or untreated controls before allowing them to feed on plants. To ensure that all plants received the same amount of damage, the caterpillars were placed in clip cages and were removed after they ate the enclosed leaf area. To test the effect of bacteria from caterpillars' oral secretions in the regulation of JA-mediated plant defenses, plants were mechanically wounded and were treated with $20 \mu$ of regurgitant diluted 1:100 in Milli-Q (MQ) water obtained from fieldcollected caterpillars that were either pretreated with antibiotics or untreated controls. Bacteria present in the regurgitant of FAW caterpillars modulated JA-related defense responses in tomato and maize but in different ways. In tomato, feeding by field-collected caterpillars treated with antibiotics induced significantly higher activity of the defense-related protein polyphenol oxidase (PPO) than that induced by untreated larvae $(t=2.71, P=0.018, n=8)$ (Fig. 1A). In maize, antibiotic-treated caterpillars induced similar transcript accumulation of the JA defense-related gene maize proteinase inhibitor (mpi) than that induced by the untreated caterpillar controls $(t=0.83, P=0.428, n=6)$ (Fig. 1B). The same pattern of defense induction observed with caterpillar feeding was found when plants were treated with regurgitant from these caterpillars (Fig. 1C and D).

To identify bacteria present in regurgitant of field-gathered caterpillars, we collected secretions directly from the caterpillar's oral cavity, diluted it 1:300 in sterile MQ water, and plated $100 \mu \mathrm{l}$ of this mixture on sterile 2xYT agar plates. Individual bacterial colonies were further subcultured on $2 \mathrm{xYT}$ plates; from those, 15 bacteria samples (randomly picked) were used for identification, using the Bruker Biotyper MALDI-TOF MS (matrix-assisted laser desorption ionizationtime of flight mass spectrometry) (Bruker Daltonics, Billerica, MA, U.S.A.) system and 16S rRNA gene sequencing. We identified five different bacterial genera in the family Enterobacteriaceae (Table 1). An isolate of Pantoea sp. was further identified as Pantoea ananatis, using specific primers (Figueiredo and Paccola-Meirelles 2012). These gene sequences were deposited in GenBank and accession numbers are listed in Table 1.

To identify which bacteria from the FAW oral secretions were inducing defense responses, we applied individual bacterial isolates to mechanically wounded plants. Each isolate was grown overnight on $2 \mathrm{xYT}$ liquid media and plants were treated with $20 \mu \mathrm{l}$ (optical density at $600 \mathrm{~nm}\left[\mathrm{OD}_{600}\right]=0.1$, approximately $9.0 \times 10^{6} \mathrm{CFU} / \mathrm{ml}$ ) of it. This dose was within the range of the concentration of bacteria cultured from field-collected caterpillars (between $7.4 \times 10^{5}$ and $6 \times 10^{8} ; n=14$ ). The effect of each bacterial isolate on JA-inducible plant defense responses was compared with responses to application of liquid media alone. In tomato, two isolates, Pantoea ananatis and Enterobacteriaceae-1, suppressed the activity of the defenserelated proteins PPO and trypsin protease inhibitor (trypsin PI) but induced greater peroxidase (POX) activity when compared with media-treated plants. A Raoultella sp. and a Klebsiella sp. had no effect on PPO but suppressed POX activity and induced trypsin PI (Fig. 2A to C). In maize plants, all bacterial isolates (except for Enterobacter sp. 2 and Enterobacteriaceae-2) induced higher mpi gene expression than that induced by the liquid media (Fig. 2D). Additionally, the P. ananatis strain found in the FAW induced cell death in tomato leaves treated with bacteria, but this response was not observed on leaves treated with media only. No sign of cell death was observed in maize (Supplementary Fig. S1). Application of 2xYT growing media to wounded tomato leaves did not affect PPO activity as compared with wounding alone $\left(\mathrm{F}_{2,15}=14.33, P=0.000, n=6\right)$ (Supplementary Fig. S2), indicating that the levels of defense responses observed in the $2 \mathrm{xYT}$ treatments were likely due to mechanical damage.

\section{Plant defense responses triggered}

by FAW gut bacteria affected caterpillar growth.

To test if defense responses elicited by bacteria from the FAW gut affect caterpillar growth, plants were treated with 
individual bacterial isolates and the leaves were used to feed third-instar caterpillars $24 \mathrm{~h}$ later. Caterpillars fed on detached leaves from tomato plants treated with $P$. ananatis or Enterobacteriaceae-1 gained more weight than those fed on wounded tomato leaves treated with media only. These caterpillars gained the same amount of weight as larvae fed on leaves from unwounded control plants (Fig. 3A). In contrast, caterpillars gained less weight when fed maize leaves previously

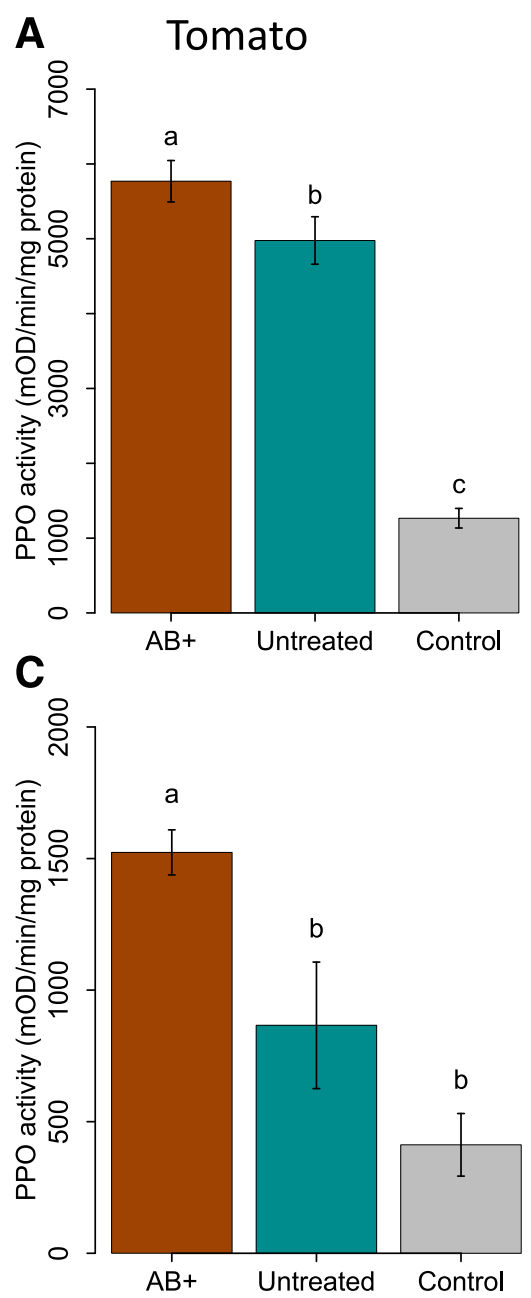

B Maize
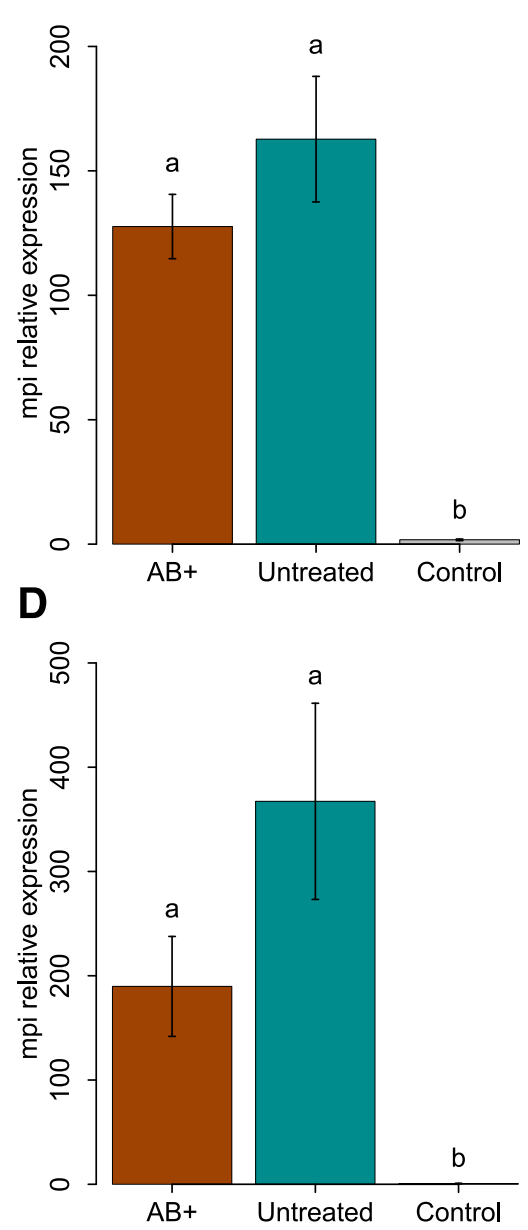

Fig. 1. Plant defense response to feeding and regurgitant treatment from field-collected fall armyworm caterpillars treated (AB+) or untreated with antibiotics. A, Polyphenol oxidase (PPO) activity in tomato plants fed on by caterpillars $\left(\mathrm{F}_{2,25}=106.10, P=0.000 ; n=8\right.$ to $11 ;$ Fisher test $)$. B, Maize proteinase inhibitor (mpi) gene expression in maize plants fed on by caterpillars $\left(\mathrm{F}_{2,9}=272.19, P=0.000 ; n=4\right.$; Fisher test; log-transformed data). $\mathbf{C}$, PPO activity in wounded tomato plants treated with caterpillar regurgitant $\left(\mathrm{F}_{2,6}=11.81, P=0.0083 ; n=3\right.$; Fisher test $)$. D, mpi gene expression in wounded maize plants treated with caterpillar regurgitant $\left(\mathrm{F}_{2,6}=176.01, P=0.000 ; n=3\right.$; Tukey test $)$. Bars are untransformed means \pm standard error of the mean; different letters indicate significant differences obtained with analysis of variance following post hoc tests at $\alpha=0.05$. Controls are undamaged plants.

Table 1. Bacteria isolates identified from fall armyworm oral secretions

\begin{tabular}{|c|c|c|c|c|c|}
\hline GenBank no. & Name used in this paper & NCBI $^{\text {a }}$ ID (\% identity) & RDP $^{\mathbf{a}}$ ID & Biotyper ID & Biotyper score \\
\hline KX161909 & Pantoea ananatis & Pantoea ananatis $(99 \%)$ & Pantoea sp. & Pantoea ananatis & 2.443 \\
\hline KX161910 & Enterobacter sp. 1 & E. cloacae & Enterobacter sp. & E. asburiae & 2.304 \\
\hline & & E. ludwigii $(99 \%)$ & & E. ludwigii & 2.264 \\
\hline KX161911 & Enterobacteriaceae-1 & $\begin{array}{l}\text { Rahnella aquatilis } \\
\text { Serratia quinivorans }(99 \%)\end{array}$ & Serratia sp. & Rahnella aquatilis & 2.099 \\
\hline KX161912 & Raoultella sp. & Raoultella ornithinolytica (99\%) & Raoultella sp. & $\begin{array}{l}\text { Raoultella ornithinolytica } \\
\text { Raoultella planticola }\end{array}$ & $\begin{array}{l}2.363 \\
2.362\end{array}$ \\
\hline KX161913 & Klebsiella sp. & Klebsiella oxytoca $(97 \%)$ & Enterobacteriaceae & Klebsiella oxytoca & 2.322 \\
\hline KX161914 & Enterobacter sp. 2 & Enterobacter sp. (99\%) & Enterobacter sp. & $\begin{array}{l}\text { E. cloacae } \\
\text { E. asburiae }\end{array}$ & $\begin{array}{l}2.031 \\
2.029\end{array}$ \\
\hline KX161915 & Enterobacteriaceae-2 & $\begin{array}{l}\text { E. ludwigii } \\
\text { Pantoea sp. } \\
\text { Pantoea dispersa }(99 \%)\end{array}$ & Enterobacteriaceae & Pantoea $^{\mathrm{b}}$ agglomerans & 1.816 \\
\hline
\end{tabular}

${ }^{a}$ NCBI = National Center for Biotechnology Information, RDP = Ribosomal Database Project.

${ }^{b}$ Not reliable identification. 

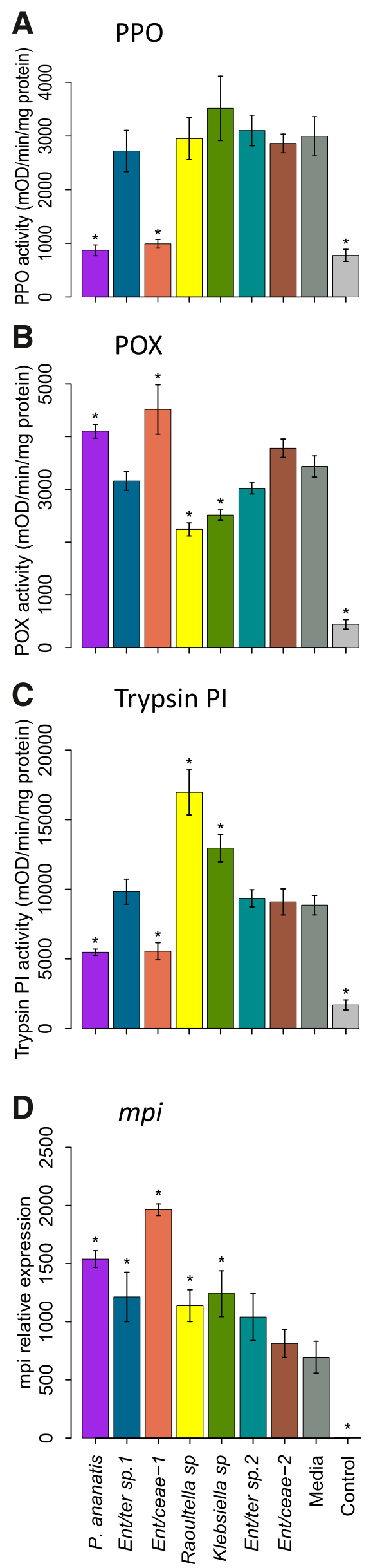

treated with $P$. ananatis and Enterobacteriaceae-1 (Fig. 3B). Caterpillars grown on leaves treated with Enterobacter sp. 1 gained the same amount of weight as those fed on wounded leaves treated with media or untreated control plants.

\section{FAW caterpillars secreted regurgitant} onto plants during feeding.

To verify that FAW caterpillars regurgitate while feeding on plants, we fed caterpillars with a florescent dye and quantified the amounts of regurgitant secreted on the feeding sites, following a procedure previously described (Peiffer and Felton 2009). All caterpillars tested $(n=20)$ regurgitated on plants (Fig. 4). On average, each caterpillar secreted $1.55( \pm 0.460)$ and $3.29( \pm 0.290) \mathrm{nl}$ of regurgitant per feeding bout on maize and tomato, respectively (Fig. 4).

\section{Pantoea ananatis was secreted onto plants during FAW feeding.}

To confirm that $P$. ananatis was modulating JA-related plant defense responses observed following caterpillar feeding, this bacterium was cultured, was diluted in $\mathrm{MgCl}_{2}$ solution, and was reintroduced into antibiotic-treated caterpillars, prior to placing them on plants. In tomato, caterpillars with reintroduced $P$. ananatis suppressed PPO activity in plants they were fed on compared with plants fed on by caterpillars without added bacteria $(t=-3.08, P=0.0132 ; n=5-6)$ (Fig. 5A). In maize, expression levels of mpi were the same regardless of the presence of $P$. ananatis in FAW that fed on these plants $(t=-0.28$, $P=0.779 ; n=10)$ (Fig. 5B).

We verified that $P$. ananatis came into contact with damaged plant tissue during caterpillar feeding by doing polymerase chain reaction (PCR) on the bacteria grown close to the feeding sites. P. ananatis was detected on $100 \%(n=14)$ of the tomato plants and on $60 \%(n=10)$ of the maize plants fed on by caterpillars with reintroduced bacteria. $P$. ananatis was not found on plants fed on by caterpillar controls treated with antibiotics and $\mathrm{MgCl}_{2}$ solution (Fig. 5C and D).

\section{FAW gut bacteria did not affect the activity of caterpillar salivary enzymes or the relative abundance of salivary proteins.}

In addition to regurgitant, FAW caterpillars also secrete saliva when feeding on plants (Chuang et al. 2014). Because this saliva contains components that induce JA-related plant defenses, it is possible that the inoculation with bacteria may affect the caterpillar salivary composition. We tested the effect of $P$. ananatis and Enterobacteriaceae-1 on the activity of two salivary enzymes, GOX and PLC. The activity of these enzymes in salivary glands from caterpillars with reintroduced bacteria was not significantly different from the activity of caterpillar controls treated with buffer (Supplementary Fig. S3). We further tested if the presence of $P$. ananatis would affect the qualitative and quantitative abundance of salivary proteins of this insect. $P$. ananatis was reintroduced

Fig. 2. Plant defense response to wounding plus the application of bacteria cultured from regurgitant of fall armyworm caterpillars. A, Polyphenol oxidase $(\mathrm{PPO})$ activity in tomato plants $\left(\mathrm{F}_{8,64}=16.74, P=0.000 ; n=8\right.$ to 10 ; Fisher test). B, Peroxidase (POX) activity in tomato $\left(\mathrm{F}_{8,63}=37.56, P=\right.$ $0.000 ; n=8$; Fisher test). C, Trypsin proteinase inhibitor (Trypsin PI) activity in tomato $\left(\mathrm{F}_{8,65}=18.93, P=0.000 ; n=5\right.$ to 10 ; Fisher test). D, Maize proteinase inhibitor (mpi) gene expression in maize plants $\left(\mathrm{F}_{8,50}=\right.$ 183.94, $P=0.000 ; n=5$ to 10 ; Fisher test; log-transformed data). Bars are untransformed means \pm standard error of the mean; asterisks (*) indicate significant differences from media-treated plants obtained with analysis of variance following post hoc tests at $\alpha=0.05$. Ent/ter $=$ Enterobacter, Ent/ceae $=$ Enterobacteriaceae , and control = undamaged plants. 
into last-instar caterpillars and saliva was collected for proteomics analysis, using isobaric tags for relative and absolute quantification (iTRAQ); a control saliva sample was collected from caterpillars treated with antibiotics and supplemented with buffer. There were 4,936 spectra identified at the $95 \%$ confidence level out of 315,667 MS/MS spectra generated. From the spectra identified, 1,840 were distinct peptides. The salivary protein abundances from caterpillars with reintroduced $P$. ananatis were not significantly different (local false discovery rate [qLFDR] > 0.05) from that of caterpillars treated with antibiotics and $\mathrm{MgCl}_{2}$ solution (Supplementary Table S1).

\section{Bacteria from FAW were present}

in other insect species feeding on maize.

We tested if the same bacterial taxa detected in the gut of FAW caterpillars were present in different insect species found in maize fields in 2014 and 2015. We identified bacteria from the regurgitant of the corn earworm Helicoverpa zea, European corn borer Ostrinia nubilalis, and black cutworm Agrotis ipsilon larvae, using $16 \mathrm{~S}$ rRNA sequencing. We found $P$. ananatis in the regurgitant of black cutworms, while Enterobacteriacea-1 and Enterobacter sp. 1 were found in corn earworm larvae (Supplementary Fig. S4).

\section{$P$. ananatis was found in FAW caterpillar frass.}

During feeding, caterpillars deposit large amounts of frass that come into contact with wounded plant sites, which elicits plant defense responses (Ray et al. 2015). We tested if $P$. ananatis reintroduced into FAW could be detected in caterpillar frass. This bacterium was found on $60 \%$ of the samples tested $(n=10)$ (Supplementary Fig. S5).

\section{Bacteria from FAW oral secretions did not affect caterpillar growth.}

We tested the effect of seven bacteria isolates from FAW regurgitant on the relative growth rate of young caterpillars. Caterpillars grown on artificial diet containing bacteria gained the same weight as larvae fed on artificial diet without bacteria. There was only one bacteria isolate, a Raoultella sp., that enhanced caterpillar growth (Supplementary Fig. S6).

\section{DISCUSSION}

Bacteria from the oral secretions of FAW caterpillars modulated JA-mediated plant defenses in response to caterpillar feeding, which affected the performance of this insect on specific hosts. In tomato, wounded plants treated with either field-collected caterpillars or their regurgitant induced lower antiherbivore defenses compared with caterpillars treated with antibiotics (Fig. 1A and C). Conversely, maize antiherbivore defense responses were not different in plants fed on by caterpillars with or without their associated bacteria (Fig. 1B and D). These results suggest that, in addition to fatty acid amino acid conjugates, proteolytic fragments, and hydrolytic enzymes (Schmelz 2015), the oral secretions of lepidopteran caterpillars also contain microbes able to modulate JA-mediated defense responses in some plant species.

From the microbial community present in the oral secretions of wild FAW caterpillars, we identified five different bacteria genera belonging to the family Enterobacteriaceae, which are commonly associated with phytophagous insects (Sugio et al. 2015). Five out of seven of these bacterial isolates elicited defense responses in tomato and maize upon their application to wounded leaves (Fig. 2). Of these, P. ananatis and Enterobacteriaceae-1 (genus Serratia/Rahnella) suppressed herbivore defenses in tomato compared with controls treated with culture media. Similar results were obtained when plants were fed on by caterpillars reinoculated with cultured $P$. ananatis (Fig. 5A). These results confirm that plant JA-mediated defenses were, in fact, being regulated by the presence of at least one of these bacterial isolates. However, it is possible that other bacterial taxa not identified by our methods could have contributed to the observed plant defense responses. Our results also showed that FAW caterpillars actively secreted regurgitant on their feeding sites (Fig. 4). Furthermore, $P$. ananatis was deposited onto the plants during caterpillar feeding (Fig. 5C and D). This suggests that bacteria from the FAW oral secretions can easily come in contact with plant wounds, where they can directly modulate JA-mediated defense responses. Our results agree with a previous study in which bacteria associated with the phytophagous Colorado potato beetle Leptinotarsa decemlineata suppressed herbivoreinduced defenses in tomato plants (Chung et al. 2013). But to our knowledge, this is the first report of this phenomenon in lepidoptera.

The effect of FAW-associated bacteria on JA-related plant defense responses appears to be host plant-specific. In tomato plants, $P$. ananatis and Enterobacteriaceae-1 suppressed herbivore defenses but, in maize, these bacterial isolates, along
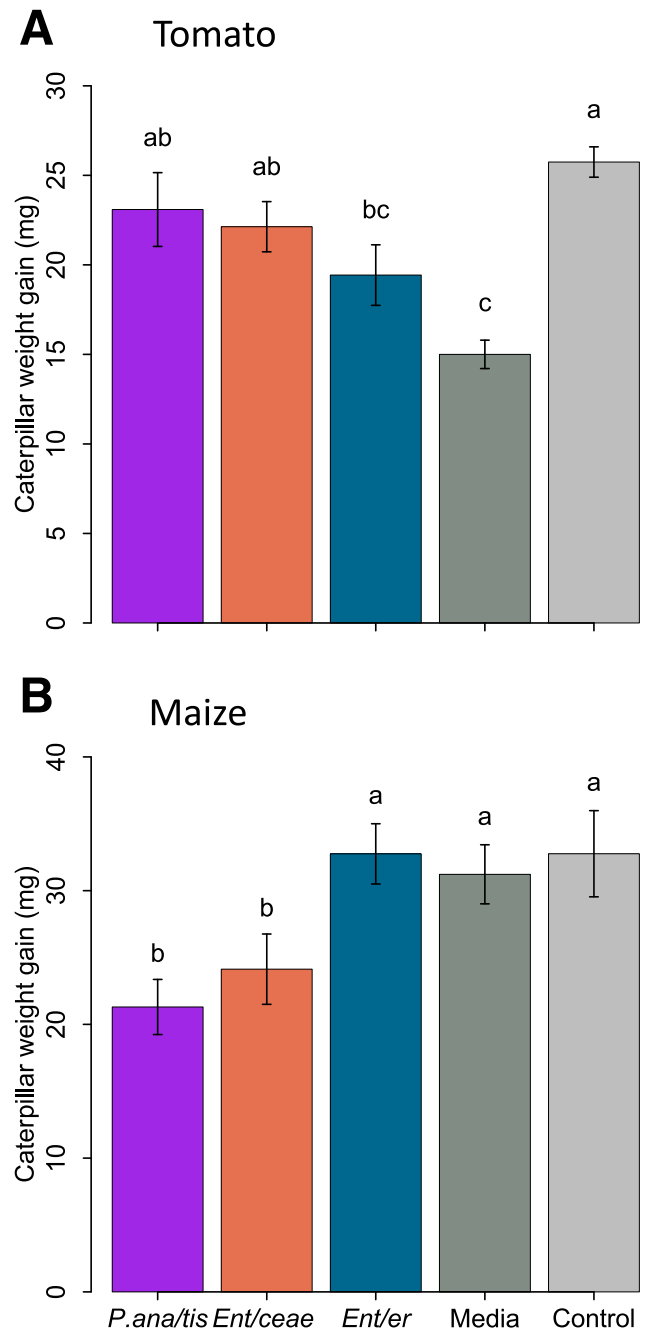

Fig. 3. Caterpillar weight gain after feeding on wounded plants treated with bacteria from fall armyworm regurgitant. A, Weight gain $(\mathrm{mg})$ of caterpillars fed on treated tomato plants $\left(\mathrm{F}_{4,45}=8.98, P=0.000 ; n=10\right.$; Tukey test; log-transformed data). B, Weight gain $(\mathrm{mg})$ of caterpillars fed on treated maize plants $\left(\mathrm{F}_{4,25}=6.24, P=0.000 ; n=4\right.$ to 8; Fisher test; log-transformed data). Bars are untransformed means \pm standard error of the mean; different letters indicate significant differences obtained with analysis of variance following post hoc tests at $\alpha=0.05$. Ent/aceae $=$ Enterobacteriaceae-1, Ent/bacter $=$ Enterobacter $\mathrm{sp}$. strain 1, and control $=$ undamaged plants. 
with Enterobacter sp. 1, Raoultella sp., and Klebsiella sp., induced transcript accumulation of the protease inhibitor gene $m p i$ (Fig. 2). This could be due to differences in signal transduction pathways or receptor-mediated recognition between these two host plants. Interestingly, when maize plants were treated with either wild caterpillars or caterpillars with reintroduced bacteria, there was a trend for mpi induction, but this effect was not significantly different from controls (Figs. 1B and $5 \mathrm{~B}$ ). This could be explained by the low regurgitation rates of the FAW when feeding on maize (Fig. 4B) or by adverse interactions of these bacteria with fragmented maize leaves inside the insect gut. It has been reported that diet type and their associated chemical defenses modify the composition of insect microbial communities in lepidopterans (Mason et al. 2015; Priya et al. 2012).
Members of the same bacterial genera identified in the oral secretions of FAW caterpillars have been reported in other Lepidoptera species, with the most common being Pantoea spp. and Enterobacter spp. (Broderick et al. 2004; Priya et al. 2012; Robinson et al. 2010; Tang et al. 2012). The few studies of lepidopterans have shown a very low diversity in microbial composition of this group, with some overlap of specific taxa (Sugio et al. 2015). The highly alkaline conditions of lepidopteran midguts may negatively correlate with levels of microbial diversity and, therefore, may select for a few taxa able to tolerate these conditions (Engel and Moran 2013).

Some of the bacterial isolates associated with field-collected FAW were also found in the regurgitant of Helicoverpa zea and Agrotis ipsilon feeding on maize in the same field. This suggests that these bacteria may have been acquired from their
A

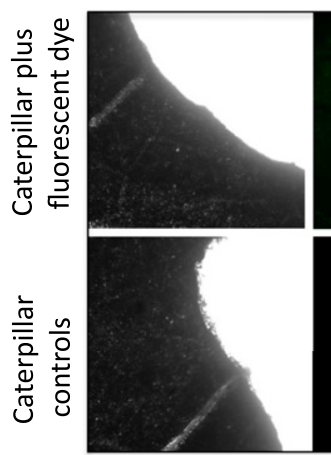

Light

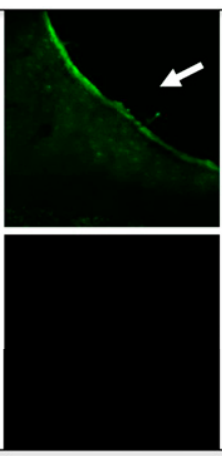

Fluorescent

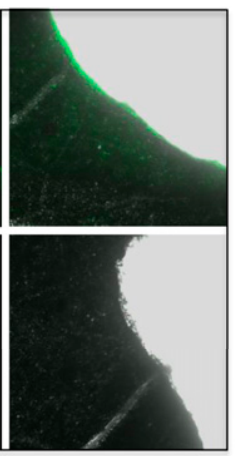

Merged
B Maize

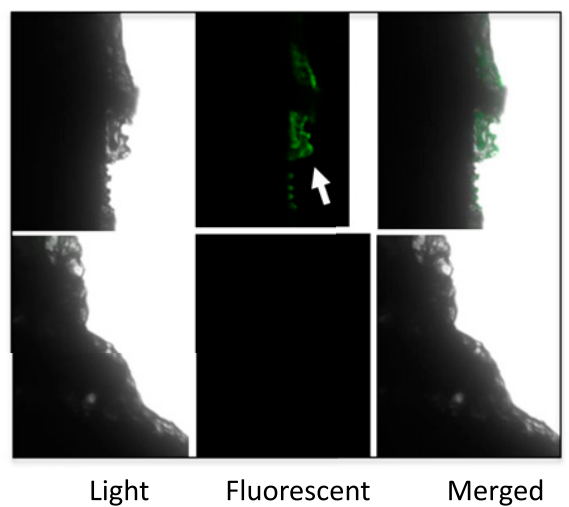

Fig. 4. Detection of regurgitant secreted by fall armyworm caterpillars on $\mathbf{A}$, tomato and $\mathbf{B}$, maize leaves using fluorescent microscopy.

A

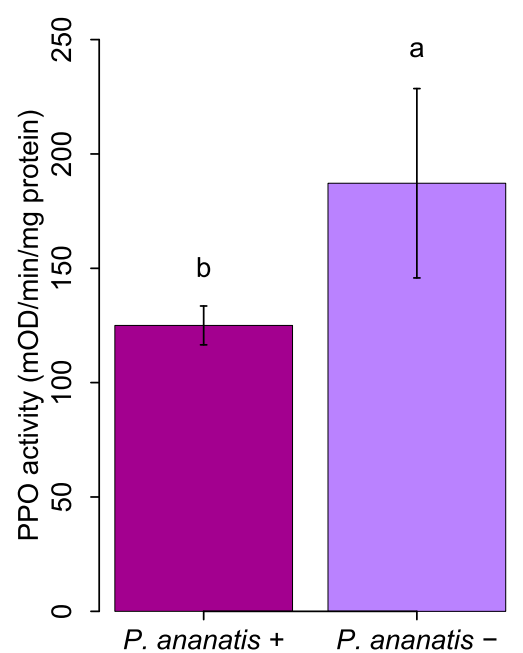

B Maize

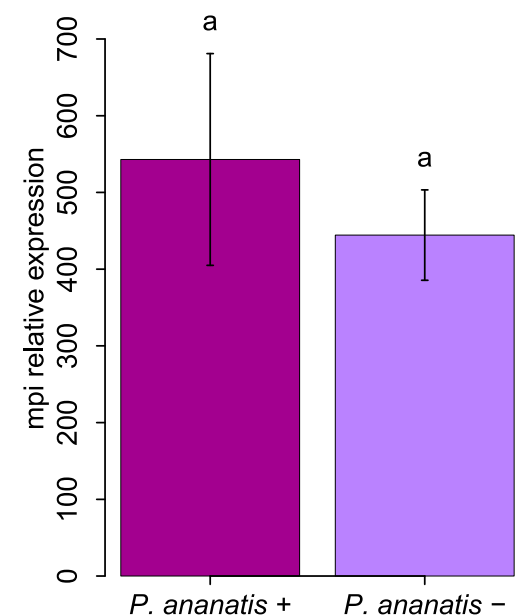

\section{C}

D

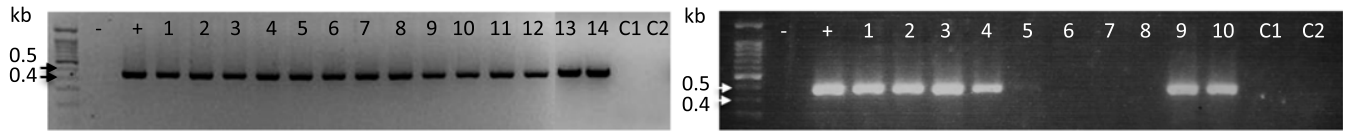

Fig. 5. Plant defense response to caterpillar feeding with (Pantoea ananatis+) or without (P. ananatis-) reintroduced P. ananatis. A, Polyphenol oxidase (PPO) activity in tomato plants $(t=-3.08, P=0.0132 ; n=5$ to 6$)$. $\mathbf{B}$, Maize proteinase inhibitor (mpi) gene expression in maize plants $\left(\mathrm{F}_{2,27}=529, P<0.001 ; n=10\right.$; Fisher test; log-transformed data). C, Presence of P. ananatis in tomato leaves fed on by caterpillars with reintroduced bacteria. D, Detection of $P$. ananatis in maize leaves fed on by caterpillars with reintroduced bacteria. $\mathbf{C}$ and $\mathbf{D}$, Agarose gel images of the negative (-) and positive (+) polymerase chain reaction controls. Lanes 1 to 14 and 1 to 10, respectively, are samples of regurgitant from caterpillars with reintroduced P. ananatis, while C1 and C2 are regurgitant samples from caterpillar controls. Bars are untransformed means \pm standard error of the mean; different letters indicate significant differences obtained with analysis of variance following post hoc tests at $\alpha=0.05$. Controls are undamaged plants. 
common host plant. Studies in other lepidopterans show that a great proportion of larval gut bacteria are obtained from the host they feed on (Mason and Raffa 2014; Priya et al. 2012). However, the composition of gut bacterial communities is also influenced by the taxonomic group to which an insect species belongs (Colman et al. 2012); this may partially explain why none of the FAW-associated bacteria were found in Ostrinia nubilalis, although the methods used in this study only partially surveyed the bacterial community of these insects. Furthermore, the effect of these bacteria on plant defense regulation may be different when associated with different caterpillar hosts. It has been shown that not all caterpillars secrete oral secretions during their feeding activity (Peiffer and Felton 2009), which may be explained by differences in their gut morphology. Caterpillars that usually regurgitate seem to have larger crops and smaller midguts than the ones that do not (Grant 2006).

The mechanisms by which FAW-associated bacteria regulate JA-inducible plant defenses are unknown. Our results show that these bacteria i) were present in the insect oral secretions, ii) regulated herbivore-induced defenses when applied to wounded plants, iii) were secreted onto the plants by insect regurgitation, and iv) had no effect on either the activity or the protein abundance of FAW saliva. Therefore, our results suggest that either the bacteria themselves or bacteriaderived components are eliciting specific plant defensive pathways. In addition, FAW benefited from its association with gut bacteria by downregulation of JA-mediated defenses in some plant hosts without an apparent effect on its growth and development.

Some strains of $P$. ananatis, one of the defense-suppressing bacteria in tomato plants, have been previously reported as pathogens of several plant species, including maize and tomato (Coutinho and Venter 2009). The specific strain of $P$. ananatis found in FAW induced cell death in tomato and may be pathogenic. $P$. ananatis has an extraordinary capacity to adapt to different environmental conditions. For example, it can have an endophytic, epiphytic, pathogenic, or symbiotic association with its host plants (Coutinho and Venter 2009). It can also be found as a symbiont in insect guts (Murrell et al. 2003; Wells et al. 2002) and as a pathogen to humans (De Baere et al. 2004). The ability of $P$. ananatis to live in an insect gut facilitates its transmission to host plants; this bacterium is vectored by the tobacco thrips Frankliniella fusca (Wells et al. 2002). Insects are common vectors of plant-pathogenic bacteria; e.g., Pantoea stewarti, the causal agent of Stewart's wilt disease in maize, is vectored by the corn flea beetle Chaetocnema pulicularia, possibly through their frass (Nadarasah and Stavrinides 2011). Although not tested in this study, $P$. ananatis could potentially be vectored by FAW caterpillars and transmitted through the insect oral secretions and possibly frass. Pathogenicity of $P$. ananatis and $P$. stewarti seems to be regulated by quorumsensing (QS) signal molecules that activate the production of exopolysaccharides and the formation of biofilms leading to infection (Koutsoudis et al. 2006; Morohoshi et al. 2007). $P$. ananatis produces two QS molecules, $N$-acyl-L-homoserine lactone and $N$-(3-oxohexanoyl)-L-homoserine lactone (Morohoshi et al. 2007). From these, the former activates SA-mediated defense responses in tomato and Arabidopsis thaliana (Schenk et al. 2014; Schuhegger et al. 2006). FAW-associated bacteria are likely to be recognized by the plant as a MAMP (microbeassociated molecular pattern), therefore inducing pathogen defenses that downregulate herbivore defenses by crosstalk between signaling pathways.

We conclude that FAW gut-associated microbes regulate herbivore-induced defenses and enhance the insect performance on tomato plants. P. ananatis and Enterobacteriaceae-1 (genus
Serratia/Rahnella) were two of the JA defense-suppressing bacteria identified in FAW oral secretions. These bacteria did not alter salivary protein abundance or the activity of insect salivary enzymes; therefore, they appear to directly regulate plant defenses upon their secretion through insect regurgitant and perhaps frass. This study contributes to our understanding of the mechanisms of plant defense regulation by lepidopteran caterpillars.

\section{MATERIALS AND METHODS}

\section{Insects.}

FAW caterpillars were collected in summer 2014 from susceptible non-Bt maize fields (Zea mays cv. Providence) at the Russell E. Larson Agricultural Research Center located at Rock Springs, Pennsylvania. This colony was then maintained under laboratory conditions (The Pennsylvania State University, University Park, U.S.A.), feeding exclusively on corn leaves for 14 generations.

\section{Plants.}

Tomato plants (Solanum lycopersicum cv. Betterboy) were grown in Promix potting soil (Premier Horticulture, Quakertown, PA, U.S.A.), fertilized once with $2 \mathrm{~g}$ of Osmocote plus (15-9-12; Scotts, Marysville, OH, U.S.A.), and were used for experiments when their fifth leaf was fully expanded. Maize plants (Zea mays cv. B73 inbred line) were grown in Hagerstown loam soil, fertilized once with $3 \mathrm{~g}$ of Osmocote plus, and were used at their V8-V9 physiological stage. Plants were grown under glasshouse conditions (14 h of light and $10 \mathrm{~h}$ of dark) at The Pennsylvania State University.

\section{Identification of gut bacteria.}

Regurgitant for bacteria identification was obtained from field-collected caterpillars on the same day they were gathered from the field. The regurgitant was collected directly from the caterpillar's oral cavity, using a $200-\mu$ l pipette, and was diluted 1:300 in sterile MQ water and $100 \mu \mathrm{l}$ of this mixture was plated on sterile $2 \mathrm{xYT}$ media; the media contained, per milliliter, $0.016 \mathrm{~g}$ of Bacto tryptone (Becton Dickinson \& Co., Sparks, MD, U.S.A.), $0.01 \mathrm{~g}$ of Bacto yeast extract (Becton Dickinson \& Co.), $0.005 \mathrm{~g}$ of sodium chloride (BDH, Toronto, Canada), and $0.014 \mathrm{~g}$ of agar (Bioserv, Newark, DE, U.S.A.). Cultures were incubated overnight at $27^{\circ} \mathrm{C}$. Individual bacterial colonies were subcultured on 2xYT agar plates. After $24 \mathrm{~h}$, individual colonies were randomly selected and were grown overnight in $2 \mathrm{xYT}$ liquid media (without agar), at $27^{\circ} \mathrm{C}$, on a rotary shaker at $200 \mathrm{rpm}$. One volume of each liquid bacteria culture was mixed with one volume of sterile $50 \%$ glycerol and was stored at $-80^{\circ} \mathrm{C}$ for further use. Bacterial identification was carried out using two methods: the Bruker Biotyper MALDI-TOF MS (Bruker Daltonics) system and 16S rRNA gene sequencing.

For the Biotyper, bacteria isolates were prepared for analysis using a direct transfer method, following a standard Bruker protocol (Schmitt et al. 2013). Briefly, individual colonies from overnight cultures (grown in 2xYT agar plates) were transferred onto a MALDI target plate, using a wooden toothpick, and were allowed to dry. The cells were lysed by applying $1 \mu \mathrm{l}$ of matrix solution (10 mg of $\alpha$-cyano-4-hydroxycinnamic acid per milliliter) in $50 \%$ aqueous acetonitrile containing $2.5 \%$ of trifluoroacetic acid. The matrix-analyte mixture was allowed to dry and the resulting samples were used for the MALDI Biotyper data acquisition. A bacterial test standard (Bruker Daltonics) was used for instrument calibration and as a positive control. Matrix blank spots were included in each analysis to ensure that the target plate was thoroughly cleaned and there was no carryover signal. MALDI mass spectra were acquired on a Bruker Ultraflextreme MALDI TOF/TOF mass 
spectrometer in the linear, positive-ion mode. Spectra were processed using a factory default processing method for the Biotyper application and were searched against a Bruker Taxonomy library containing 5,627 cellular organism entries using MALDI Biotyper version 3.1 software. Manufacturerrecommended cutoff scores were used for identification. Scores $\geq 2.0$ indicate identification to the species level, scores between 1.7 and 1.999 indicate identification to the genus level and scores of $<1.7$ indicate no identification.

The 16S rRNA sequences were analyzed using BLAST against the nucleotide database of the National Center for Biotechnology Information and the Ribosomal Database Project naive Bayesian rRNA classifier version 2.1 , at the $95 \%$ confidence threshold (Wang et al. 2007). The PCR reaction contained $0.4 \mu \mathrm{M}$ of each universal 16S rRNA primer (530 F 5'-GTG CCA GCM GCC GCG G-3' and 1392R 5'-ACG GGC GGT GTG TRC-3'), $12.5 \mu \mathrm{l}$ of the GoTaq Green master mix (Promega, Madison, WI, U.S.A.), $2 \mu \mathrm{l}$ of the overnight liquid-grown bacteria previously diluted 1:5 in sterile water, and $8.5 \mu \mathrm{l}$ of MQ water, for a total volume of $25 \mu \mathrm{l}$. The PCR conditions had an initial denaturation step of $5 \mathrm{~min}$ at $95^{\circ} \mathrm{C}$, followed by 30 cycles of $95^{\circ} \mathrm{C}$ for $1 \mathrm{~min}$, $57^{\circ} \mathrm{C}$ for $30 \mathrm{~s}$, and $72^{\circ} \mathrm{C}$ for $1 \mathrm{~min}$, and a final extension step of $7 \mathrm{~min}$ at $72^{\circ} \mathrm{C}$. The samples were cleaned up from remaining primers and nucleotides by incubating $5 \mu$ of the PCR product with $2 \mu \mathrm{l}$ of EXOSAP-IT (USB Corporation, Cleveland) at $37^{\circ} \mathrm{C}$ for $15 \mathrm{~min}$, followed by a denaturation step at $80^{\circ} \mathrm{C}$ for $15 \mathrm{~min}$ to inactivate the EXOSAP-IT reagent. The PCR products were subjected to Sanger sequencing at The Pennsylvania State University Genomics Core Facility.

\section{Effect of caterpillar gut bacteria on herbivore-induced plant defense responses.}

The effect of caterpillar gut bacteria on herbivore-induced defenses in tomato and maize plants was tested using different strategies. First, field-collected caterpillars were either pretreated with antibiotics (discussed below) or untreated controls before allowing them to feed on plants. These caterpillars were placed on plants using clip cages (polypropylene with metallic micromesh screen, $23 \mathrm{~mm}$ diameter and $18 \mathrm{~mm}$ height) to standardize the amount of damage. Second, mechanically wounded plants were treated with regurgitant obtained from field-collected caterpillars that were either pretreated with antibiotics or untreated controls. Third, mechanically wounded plants were treated with individual bacteria $\left(\mathrm{OD}_{600}=0.1\right.$, approximately $\left.9.0 \times 10^{6} \mathrm{CFU} / \mathrm{ml}\right)$ isolated from the FAW regurgitant and grown overnight on $2 \mathrm{xYT}$ liquid media. The effect of each bacterial isolate on JA-related plant defense responses was compared with responses to application of liquid media. To determine if the 2xYT liquid media itself could induce plant defense responses, we tested its effect combined with wounding versus wounding alone. Finally, to test the effect of single bacteria isolates in combination with caterpillar feeding on JAmediated plant defense responses, individual bacteria cultures were reintroduced into caterpillars pretreated with antibiotics, which were then placed on plants. The leaf tissue (50 to $70 \mathrm{mg}$ ) around the feeding or damaged sites was harvested 24 and $48 \mathrm{~h}$ later (for maize and tomato, respectively) in liquid nitrogen and was stored at $-80^{\circ} \mathrm{C}$ for further analysis. JA-related plant defense responses were measured by assessing the activity of defense-related proteins and quantifying the expression of a JA defense-related gene. In tomato plants, we measured the activity of PPO, trypsin PI, and POX, using biochemical assays. In maize plants, we quantified the relative expression of the mpi gene using quantitative real-time PCR (qPCR).

\section{Antibiotic treatment and determination of bacteria dose.}

Caterpillars were treated with a cocktail of antibiotics containing $12.82 \mathrm{mg}$ of neomycin sulfate per milliliter (MP Biomedicals, Santa Ana, CA, U.S.A.), $64.1 \mathrm{mg}$ of aureomycin per milliliter (Bioserv) and $3.85 \mathrm{mg}$ of streptomycin sulfate per milliliter (Amresco, Solon, OH. U.S.A.) diluted in MQ water. Twenty microliters of the antibiotic cocktail were deposited as small drops onto a piece of maize leaf (approximately $2.5 \mathrm{~cm}^{2}$ ), were placed into a plate of agar, and were air dried for 3 to $4 \mathrm{~h}$. Each caterpillar was allowed to eat only one treated maize leaf piece. Untreated caterpillars were fed maize leaves treated with MQ water. The antibiotics dose used in these experiments was determined by feeding caterpillars with different concentrations of antibiotics; $24 \mathrm{~h}$ later, $1 \mu \mathrm{l}$ of regurgitant was collected from each caterpillar $(n=10)$ and was diluted in $300 \mu \mathrm{l}$ of sterile water. From this mixture, $100 \mu \mathrm{l}$ were plated on $2 \mathrm{xYT}$ agar plates and the number of bacterial colonies was counted $24 \mathrm{~h}$ later. The dose used above was chosen to produce no detectable bacterial colonies at the dilution tested.

To determine the concentration of bacteria to use in our experiments, regurgitant was collected from field-collected caterpillars and serial dilutions were plated on 2xYT agar plates to quantify the CFU per milliliters. Subsequent dilutions of cultured bacteria isolated from FAW were plated on 2xYT agar plates to determine a dilution that was comparable to the concentration of bacteria in the regurgitant of field-collected caterpillars.

\section{Reintroduction of bacteria isolates into caterpillars.}

To study the effects of individual bacteria isolates on induction of JA-mediated plant defenses, single bacteria isolates were reintroduced into caterpillars that were later allowed to feed on plants. Last-instar larvae were first treated with antibiotics (as indicated above) to clear their gut. The following day, caterpillars were fed twice with a small piece of artificial diet $(0.1 \mathrm{~g})$ containing $10 \mu \mathrm{l}$ of bacteria $\left(\mathrm{OD}_{600}=1.0\right.$, approximately $9.0 \times 10^{6} \mathrm{CFU} / \mathrm{ml}$ ) resuspended in $10 \mathrm{mM}$ of $\mathrm{MgCl}_{2}$. The bacteria isolates were grown overnight in $2 \mathrm{xYT}$ liquid media, the bacteria suspension was centrifuged at $5,000 \times g$ for $10 \mathrm{~min}$, and the pellet was resuspended in $\mathrm{MgCl}_{2}$ solution (Chung et al. 2013). Control caterpillars were fed diet and $\mathrm{MgCl}_{2}$ only. After the diet was eaten (overnight), all caterpillars were transferred into a new cup and were fed with untreated $2.5-\mathrm{cm}^{2}$ leaf pieces before placing them on the plants ( 2 to $3 \mathrm{~h}$ ).

\section{Effect of induced plant defenses on caterpillar growth.}

We evaluated the effect of plant defense responses elicited by bacteria isolates from the FAW gut on caterpillar growth. Plants were mechanically wounded and were treated with $20 \mu \mathrm{l}$ of either liquid media or individual bacteria cultures $\left(\mathrm{OD}_{600}=0.1\right.$. approximately $9.0 \times 10^{6} \mathrm{CFU} / \mathrm{ml}$ ) grown overnight on $2 \times \mathrm{YT}$ liquid media. These bacterial cultures were uniformly applied over the wounded area (approximately $28 \mathrm{~mm}^{2}$ ). After 24 and $48 \mathrm{~h}$ (for maize and tomato, respectively), the treated leaves were detached and were used to feed third-instar FAW caterpillars for 6 days. The entire treated leaf of each plant was used to feed three caterpillars, and their average weight gain was used as an independent biological replicate for the statistical analysis. The caterpillar weight gain was calculated as the difference between initial and final weight.

\section{Quantification of regurgitant on plant leaves.}

We quantified the amount of regurgitant secreted by the FAW caterpillars feeding on tomato and maize plants, following the procedure described by Peiffer and Felton (2009). Caterpillars were grown from egg hatch on maize leaves and were used when they reached their last instar. The fluorescent dye Alexa Fluor $488(10 \mu \mathrm{g})$ (Invitrogen, Carlsbad, CA, U.S.A.) was diluted in water and was deposited onto the surface of leaves as 
small drops, using a micropipette. These drops were allowed to dry for approximately $3 \mathrm{~h}$ at room temperature in the dark. The leaf pieces were kept inside a petri dish containing $1 \%$ agar to avoid excessive dehydration. After the caterpillars ate the whole dye or water-treated leaf pieces, they were transferred to a new plastic cup and were allowed to feed on fresh untreated leaves for about $2 \mathrm{~min}$ and, then, the leaf pieces were used for detection of fluorescence. The amount of secreted regurgitant was measured using a standard curve.

\section{Detection of specific bacteria on plant leaves.}

To verify that gut bacteria come into contact with plant wounds during caterpillar feeding, FAW caterpillars with reintroduced Pantoea ananatis, a bacterium found in the FAW gut, were allowed to feed on plants for 30 to $60 \mathrm{~min}$. The tissue around the feeding sites was harvested with clean scissors and forceps, was placed into a sterile $2-\mathrm{ml}$ tube containing $2 \mathrm{xYT}$ liquid media, and was incubated overnight at $27^{\circ} \mathrm{C}$ in a rotary shaker at $200 \mathrm{rpm}$. Caterpillars treated with antibiotics and fed with $\mathrm{MgCl}_{2}$ only were used as negative controls. The presence of $P$. ananatis in the bacteria culture was detected by PCR, using specific primers developed by Figueiredo and PaccolaMeirelles (2012). The PCR reaction contained $0.4 \mu \mathrm{M}$ of each primer (ANAF: 5'-CGT GAA ACT ACC CGT GTC TGT TGC -3' and EC5: 5'-TGC CAG GGC ATC CAC CGT GTA CGC T3'), $12.5 \mu$ l of the GoTaq Green master mix (Promega), $2 \mu \mathrm{l}$ of the overnight liquid-grown bacteria previously diluted 1:5 in sterile water, and $8.5 \mu \mathrm{l}$ of MQ water for a total volume of $25 \mu \mathrm{l}$. The PCR conditions had an initial denaturation step of $5 \mathrm{~min}$ at $95^{\circ} \mathrm{C}$, followed by 35 cycles of $95^{\circ} \mathrm{C}$ for $1 \mathrm{~min}, 60^{\circ} \mathrm{C}$ for $30 \mathrm{~s}$, and $72^{\circ} \mathrm{C}$ for $1 \mathrm{~min}$, and a final extension step of $5 \mathrm{~min}$ at $72^{\circ} \mathrm{C}$. The DNA fragments were separated on a $2 \%$ agarose gel run in $1 \times$ Tris-acetate-EDTA at $75 \mathrm{~V}$ for $45 \mathrm{~min}$ and were then stained with SYBR green for visualization under UV light.

\section{Protein activity assays.}

The activity of PPO and trypsin PI were measured as described previously (Chung and Felton 2011). The trypsin PI activity was calculated as PI $(\%)=(1-($ slope of sample/slope of noninhibitor) $\times 100$, and the resulting activity values were normalized by the amount of protein (milligrams per milliliter) or the amount of fresh leaf tissue (grams) contained in the sample. POX activity was assayed as described by $\mathrm{Bi}$ and Felton (1995), with minor modifications; $50 \mathrm{mg}$ of leaf tissue was ground in liquid nitrogen and was homogenized in $1.25 \mathrm{ml}$ of $0.1 \mathrm{M}$ potassium phosphate buffer $(\mathrm{pH} 7.0)$ containing $5 \%$ of cross-linked polyvinylpyrrolidone (Alfa Aesar, Ward Hill, MA, U. S.A.), and was centrifuged at $11,000 \times g$ for $10 \mathrm{~min}$ at $4^{\circ} \mathrm{C}$. The supernatant $(5 \mu \mathrm{l})$ was mixed with $10 \mu \mathrm{l}$ of $3 \% \mathrm{H}_{2} \mathrm{O}_{2}$ and $190 \mu \mathrm{l}$ of $3 \mathrm{mM}$ guaiacol (MP Biomedicals). The change in absorbance was measured at $450 \mathrm{~nm}$ for $5 \mathrm{~min}$. GOX activity in the caterpillar salivary glands was measured as described previously (Eichenseer et al. 1999) and was adjusted for a microplate reader. PLC enzymatic assays followed a protocol described previously (Kurioka and Matsuda 1976; Le Chevalier et al. 2015) and adapted for a microplate reader.

\section{Effect of bacteria on FAW salivary protein abundance.}

Saliva for proteomic analysis was collected from last-instar caterpillars with and without reintroduced $P$. ananatis (following the procedure described above). FAW caterpillars were chilled on ice for $45 \mathrm{~min}$ and were immobilized within a metallic hairclip. As caterpillars warmed up, caterpillar saliva was collected, using a micropipette tip under a dissecting microscope (Olympus SZ30). Two saliva samples, each containing $10 \mu \mathrm{g}$ of saliva and $0.4 \mu \mathrm{g}$ of protease inhibitor (P2714; Sigma, St. Louis) diluted in $10 \mu \mathrm{l}$ of MQ water, were used for proteomic analysis using iTRAQ. The protein samples were prepared following The Pennsylvania State University College of Medicine Mass Spectrometry and Proteomics Core Facility standard protocol (Supplementary Methods) adapted from the manufacturer's instructions (Applied Biosystems, Carlsbad, CA, U.S.A.).

\section{Presence of $\boldsymbol{P}$. ananatis in caterpillar frass.}

Along with saliva and oral secretions, caterpillars deposit frass on plants during feeding. We tested whether bacteria present in caterpillar regurgitant would also be present in caterpillar frass. Caterpillars with reintroduced $P$. ananatis were fed maize leaves for 2 days; the caterpillars were transferred to clean cups twice and fresh leaves were provided every $12 \mathrm{~h}$. At the end of the second day, fresh frass pellets were collected and placed in $2-\mathrm{ml}$ tubes with $1.5 \mathrm{ml}$ of $2 \mathrm{xYT}$ liquid media and were incubated overnight at $27^{\circ} \mathrm{C}$ in a rotary shaker at $200 \mathrm{rpm}$. The following day, $1 \mu \mathrm{l}$ of the cultured bacteria was transferred into a new tube with $1.5 \mu \mathrm{l}$ of sterile liquid media and was incubated overnight under the same conditions described above. Bacteria ( $2 \mu$ l, diluted 1:5) were used for the detection of $P$. ananatis, using PCR.

\section{Bacteria from FAW in other caterpillar species.}

We collected caterpillars feeding on insect-susceptible maize fields (cv. Providence) at the Russell E. Larson Agricultural Research Center, Rock Springs, Pennsylvania. Bacteria from caterpillar regurgitant were cultured in the same way described above for FAW. The $16 \mathrm{~S}$ region was amplified from individual bacteria cultures, using the same primers described above, and were sequenced. The sequences of bacteria genera corresponding to those found in the FAW were aligned using Clustal 1.6, with a gap opening penalty of 15 and a gap extension penalty of 6.66 . The resulting sequence alignment was used to construct phylogenetic trees using the UPGMA hierarchical clustering method. The test of phylogeny was done with the bootstrap method with 1,000 replications, using the software MEGA 5.0 (Tamura et al. 2011).

\section{Pathogenicity of $P$. ananatis to maize and tomato plants.}

Plant leaves were infiltrated with liquid cultures of $P$. ananatis $\left(\mathrm{OD}_{600}=0.1\right.$, approximately $\left.9.0 \times 10^{6} \mathrm{CFU} / \mathrm{ml}\right)$ grown overnight on 2 XYT media or liquid media alone. The plants were kept under greenhouse conditions for 5 days, time at which the leaves were detached from the plants and were photographed.

\section{Effect of bacteria on caterpillar growth.}

We tested the effect of six bacterial isolates from FAW regurgitant on the relative growth rate of FAW caterpillars. Neonates were placed on artificial diet containing antibiotics (streptomycin [5 mg per $100 \mathrm{ml}$ ] and aureomycin [100 mg per $100 \mathrm{ml}]$ ) for 5 days. Larvae were then transferred to new cups containing $0.8 \mathrm{~g}$ of artificial diet (without antibiotics) that had been inoculated with $50 \mu \mathrm{l}$ of individual bacteria isolates diluted in $10 \mathrm{mM}$ of $\mathrm{MgCl}_{2}\left(\mathrm{OD}_{600}=0.1\right.$, approximately $9.0 \times$ $10^{6} \mathrm{CFU} / \mathrm{ml}$ ). Controls received diet with $\mathrm{MgCl}_{2}$ solution alone. Fresh diet with bacteria was provided every 2 days in clean cups. The caterpillars were weighed 2 and 5 days later, and their relative growth rate was calculated as $\{(W 2-W 1) \div$ $[(W 1+W 2 / 2) \times d]\}$, where $W 1$ is the initial weight, $W 2$ is the final weight, and $d$ is the number of days between measurements (Mohan et al. 2008).

RNA extraction, cDNA synthesis, and real time PCR.

Leaf tissue (50 to $70 \mathrm{mg}$ ) frozen in liquid nitrogen was homogenized in a GenoGrinder 2000 (OPS Diagnostics, Lebanon, NJ, U.S.A.), and total RNA was extracted using a modified 
Trizol protocol. Complementary DNA (cDNA) was synthesized from $1 \mu \mathrm{g}$ of RNA using the High Capacity cDNA reverse transcription kit (Applied Biosystems), using oligo-dT following the manufacturer's protocol. qPCR) was conducted using the 7500 Fast Real-Time PCR System (Applied Biosystems) with SYBR green (Roche Applied Science, Indianapolis, IN, U.S.A.). The specific primers used for the target and reference genes (mpi and actin, respectively) were the same ones reported previously (Ray et al. 2015).

\section{Experimental design and statistical analysis.}

The plant defense response (PPO, trypsin PI, and POX activities and mpi gene expression) to different treatments (caterpillar feeding, application of caterpillar regurgitant and liquid bacteria isolates), the effect of bacteria reintroduction on the activity of GOX and PLC in the caterpillar salivary glands, and the effect of plant defense responses on caterpillar weight gain were analyzed with one-way analysis of variance, following the post hoc tests of Tukey and Fisher at $\alpha=0.05$. These statistical analyses were performed using Minitab 16 (Minitab Inc., State College, PA, U.S.A.), and all graphs were generated in $\mathrm{R}$ version 3.2.2 (Foundation for Statistical Computing, Vienna). The statistical analyses of quantitative iTRAQ were done using PSUTraq, which is an in-house modification of the MatLab program WHATraq developed by Zhou et al. (2014). In PSUTraq, we added a qLFDR, based on (Storey and Tibshirani 2003), to correct for multiple testing. This qLFDR was calculated using significant $P$ values $(<0.05)$ obtained by Protein Pilot for the ratios of two samples with similar peak intensity values. Quantitative differences in the protein composition of saliva from caterpillars treated or untreated with $P$. ananatis were analyzed using $\log 2$ ratios of their peptide abundances.

\section{ACKNOWLEDGMENTS}

We thank S. Smiles for the soil preparation and planting of maize fields. We also thank T. Laremore, director of the Huck Institutes of the Life Sciences Proteomics and Mass Spectrometry Core Facility, for the MALDI TOF mass spectra acquisition, the MBT microorganism identification, and help in the manuscript preparation and B. Jayarao, director of the Penn State Animal Diagnostics Laboratory, for providing the Biotyper software. We greatly appreciate the support of the National Science Foundation (IOS1256326) for their funding.

\section{LITERATURE CITED}

Acevedo, F. E., Rivera-Vega, L. J., Chung, S. H., Ray, S., and Felton, G. W. 2015. Cues from chewing insects-The intersection of DAMPs, HAMPs, MAMPs and effectors. Curr. Opin. Plant Biol. 26:80-86.

Bi, J. L., and Felton, G. W. 1995. Foliar oxidative stress and insect herbivory: Primary compounds, secondary metabolites, and reactive oxygen species as components of induced resistance. J. Chem. Ecol. 21: 1511-1530.

Broderick, N. A., Raffa, K. F., Goodman, R. M., and Handelsman, J. 2004. Census of the bacterial community of the gypsy moth larval midgut by using culturing and culture-independent methods. Appl. Environ. Microbiol. 70:293-300.

Chuang, W.-P., Ray, S., Acevedo, F. E., Peiffer, M., Felton, G. W., and Luthe, D. S. 2014. Herbivore cues from the fall armyworm (Spodoptera frugiperda) larvae trigger direct defenses in maize. Mol. Plant-Microbe Interact. 27:461-470.

Chung, S. H., and Felton, G. W. 2011. Specificity of induced resistance in tomato against specialist lepidopteran and coleopteran species. J. Chem. Ecol. 37:378-386.

Chung, S. H., Rosa, C., Scully, E. D., Peiffer, M., Tooker, J. F., Hoover, K., Luthe, D. S., and Felton, G. W. 2013. Herbivore exploits orally secreted bacteria to suppress plant defenses. Proc. Natl. Acad. Sci. U.S.A. 110: 15728-15733.

Colman, D. R., Toolson, E. C., and Takacs-Vesbach, C. D. 2012. Do diet and taxonomy influence insect gut bacterial communities? Mol. Ecol. 21:5124-5137.
Coutinho, T. A., and Venter, S. N. 2009. Pantoea ananatis: An unconventional plant pathogen. Mol. Plant Pathol. 10:325-335.

De Baere, T., Verhelst, R., Labit, C., Verschraegen, G., Wauters, G., Claeys, G., and Vaneechoutte, M. 2004. Bacteremic infection with Pantoea ananatis. J. Clin. Microbiol. 42:4393-4395.

Douglas, A. E. 2015. Multiorganismal insects: Diversity and function of resident microorganisms. Annu. Rev. Entomol. 60:17-34.

Eichenseer, H., Mathews, M. C., Bi, J. L., Murphy, J. B., and Felton, G. W. 1999. Salivary glucose oxidase: Multifunctional roles for Helicoverpa zea? Arch. Insect Biochem. Physiol. 42:99-109.

Engel, P., and Moran, N. A. 2013. The gut microbiota of insects-Diversity in structure and function. FEMS Microbiol. Rev. 37:699-735.

Felton, G. W., Chung, S. H., Hernandez, M. G. E., Louis, J., Peiffer, M., and Tian, D. 2014. Herbivore oral secretions are the first line of protection against plant-induced defences. Pages 37-76 in: Annual Plant Reviews. C. Voelckel, and G. Jander, eds. John Wiley \& Sons, Ltd., New York.

Felton, G. W., and Tumlinson, J. H. 2008. Plant-insect dialogs: Complex interactions at the plant-insect interface. Curr. Opin. Plant Biol. 11: 457-463.

Figueiredo, J. E., and Paccola-Meirelles, L. 2012. Simple, rapid and accurate PCR-based detection of Pantoea ananatis in maize, sorghum and Digitaria sp. J. Plant Pathol. 94:663-667.

Grant, J. B. 2006. Diversification of gut morphology in caterpillars is associated with defensive behavior. J. Exp. Biol. 209:3018-3024.

Hammer, T. J., and Bowers, M. D. 2015. Gut microbes may facilitate insect herbivory of chemically defended plants. Oecologia 179:1-14.

Hosokawa, T., Kikuchi, Y., Shimada, M., and Fukatsu, T. 2007. Obligate symbiont involved in pest status of host insect. Proc. Biol. Sci. 274: 1979-1984.

Indiragandhi, P., Anandham, R., Madhaiyan, M., and Sa, T. M. 2008. Characterization of plant growth-promoting traits of bacteria isolated from larval guts of diamondback moth Plutella xylostella (Lepidoptera: Plutellidae). Curr. Microbiol. 56:327-333.

Koutsoudis, M. D., Tsaltas, D., Minogue, T. D., and von Bodman, S. B. 2006. Quorum-sensing regulation governs bacterial adhesion, biofilm development, and host colonization in Pantoea stewartii subspecies stewartii. Proc. Natl. Acad. Sci. U.S.A. 103:5983-5988.

Kurioka, S., and Matsuda, M. 1976. Phospholipase C assay using p-nitrophenylphosphoryl-choline together with sorbitol and its application to studying the metal and detergent requirement of the enzyme. Anal. Biochem. 75:281-289.

Le Chevalier, F., Cascioferro, A., Frigui, W., Pawlik, A., Boritsch, E. C., Bottai, D., Majlessi, L., Herrmann, J. L., and Brosch, R. 2015. Revisiting the role of phospholipases $\mathrm{C}$ in virulence and the lifecycle of Mycobacterium tuberculosis. Sci. Rep. 5:16918.

Mason, C. J., Lowe-Power, T. M., Rubert-Nason, K. F., Lindroth, R. L., and Raffa, K. F. 2016. Interactions between bacteria and aspen defense chemicals at the phyllosphere-Herbivore interface. J. Chem. Ecol. 42: 193-201.

Mason, C. J., and Raffa, K. F. 2014. Acquisition and structuring of midgut bacterial communities in gypsy moth (Lepidoptera: Erebidae) larvae. Environ. Entomol. 43:595-604.

Mason, C. J., Rubert-Nason, K. F., Lindroth, R. L., and Raffa, K. F. 2015. Aspen defense chemicals influence midgut bacterial community composition of gypsy moth. J. Chem. Ecol. 41:75-84.

Mohan, S., Ma, P. W. K., Williams, W. P., and Luthe, D. S. 2008. A naturally occurring plant cysteine protease possesses remarkable toxicity against insect pests and synergizes Bacillus thuringiensis toxin. PLoS One 3: e1786.

Morohoshi, T., Nakamura, Y., Yamazaki, G., Ishida, A., Kato, N., and Ikeda, T. 2007. The plant pathogen Pantoea ananatis produces $\mathrm{N}$-acylhomoserine lactone and causes center rot disease of onion by quorum sensing. J. Bacteriol. 189:8333-8338.

Murrell, A., Dobson, S. J., Yang, X., Lacey, E., and Barker, S. C. 2003. A survey of bacterial diversity in ticks, lice and fleas from Australia. Parasitol. Res. 89:326-334.

Musser, R. O., Hum-Musser, S. M., Eichenseer, H., Peiffer, M., Ervin, G., Murphy, J. B., and Felton, G. W. 2002. Herbivory: Caterpillar saliva beats plant defences. Nature 416:599-600.

Nadarasah, G., and Stavrinides, J. 2011. Insects as alternative hosts for phytopathogenic bacteria. FEMS Microbiol. Rev. 35:555-575.

Peiffer, M., and Felton, G. W. 2009. Do caterpillars secrete "oral secretions"? J. Chem. Ecol. 35:326-335.

Ping, L., Büchler, R., Mithöfer, A., Svatos, A., Spiteller, D., Dettner, K., Gmeiner, S., Piel, J., Schlott, B., and Boland, W. 2007. A novel Dps-type protein from insect gut bacteria catalyses hydrolysis and synthesis of N-acyl amino acids. Environ. Microbiol. 9:1572-1583. 
Priya, N. G., Ojha, A., Kajla, M. K., Raj, A., and Rajagopal, R. 2012. Host plant induced variation in gut bacteria of Helicoverpa armigera. PLoS One 7:e30768.

Ray, S., Alves, P. C., Ahmad, I., Gaffoor, I., Acevedo, F. E., Peiffer, M., Jin, S., Han, Y., Shakeel, S., Felton, G. W., and Luthe, D. S. 2016. Turnabout is fair play: Herbivory-induced plant chitinases excreted in fall armyworm frass suppress herbivore defenses in maize. Plant Physiol. 171:694-706.

Ray, S., Gaffor, I., Acevedo, F. E., Helms, A., Chuang, W.-P., Tooker, J., Felton, G. W., and Luthe, D. S. 2015. Maize plants recognize herbivoreassociated cues from caterpillar frass. J. Chem. Ecol. 41:781-792.

Robinson, C. J., Schloss, P., Ramos, Y., Raffa, K., and Handelsman, J. 2010. Robustness of the bacterial community in the cabbage white butterfly larval midgut. Microb. Ecol. 59:199-211.

Schenk, S. T., Hernández-Reyes, C., Samans, B., Stein, E., Neumann, C., Schikora, M., Reichelt, M., Mithöfer, A., Becker, A., Kogel, K.-H., and Schikora, A. 2014. $\mathrm{N}$-acyl-homoserine lactone primes plants for cell wall reinforcement and induces resistance to bacterial pathogens via the salicylic acid/oxylipin pathway. Plant Cell 26:2708-2723.

Schmelz, E. A. 2015. Impacts of insect oral secretions on defoliationinduced plant defense. Curr. Opin. Insect Sci. 9:7-15.

Schmitt, B. H., Cunningham, S. A., Dailey, A. L., Gustafson, D. R., and Patel, R. 2013. Identification of anaerobic bacteria by Bruker Biotyper matrixassisted laser desorption ionization-time of flight mass spectrometry with on-plate formic acid preparation. J. Clin. Microbiol. 51:782-786.

Schuhegger, R., Ihring, A., Gantner, S., Bahnweg, G., Knappe, C., Vogg, G., Hutzler, P., Schmid, M., Van Breusegem, F., Eberl, L., Hartmann, A., and Langebartels, C. 2006. Induction of systemic resistance in tomato by $\mathrm{N}$-acyl-L-homoserine lactone-producing rhizosphere bacteria. Plant Cell Environ. 29:909-918.

Storey, J. D., and Tibshirani, R. 2003. Statistical significance for genomewide studies. Proc. Natl. Acad. Sci. U.S.A. 100:9440-9445.

Sugio, A., Dubreuil, G., Giron, D., and Simon, J.-C. 2015. Plant-insect interactions under bacterial influence: Ecological implications and underlying mechanisms. J. Exp. Bot. 66:467-478.

Tamura, K., Peterson, D., Peterson, N., Stecher, G., Nei, M., and Kumar, S. 2011. MEGA5: Molecular evolutionary genetics analysis using maximum likelihood, evolutionary distance, and maximum parsimony methods. Mol. Biol. Evol. 28:2731-2739.
Tang, X., Freitak, D., Vogel, H., Ping, L., Shao, Y., Cordero, E. A., Andersen, G., Westermann, M., Heckel, D. G., and Boland, W. 2012. Complexity and variability of gut commensal microbiota in polyphagous lepidopteran larvae. PLoS One 7:e36978.

Tian, D., Peiffer, M., Shoemaker, E., Tooker, J., Haubruge, E., Francis, F., Luthe, D. S., and Felton, G. W. 2012. Salivary glucose oxidase from caterpillars mediates the induction of rapid and delayed-induced defenses in the tomato plant. PLoS One 7:e36168.

Tsuchida, T., Koga, R., and Fukatsu, T. 2004. Host plant specialization governed by facultative symbiont. Science 303:1989.

Visôtto, L. E., Oliveira, M. G. A., Ribon, A. O. B., Mares-Guia, T. R., and Guedes, R. N. C. 2009. Characterization and identification of proteolytic bacteria from the gut of the velvetbean caterpillar (Lepidoptera: Noctuidae). Environ. Entomol. 38:1078-1085.

Wang, Q., Garrity, G. M., Tiedje, J. M., and Cole, J. R. 2007. Naive Bayesian classifier for rapid assignment of rRNA sequences into the new bacterial taxonomy. Appl. Environ. Microbiol. 73:5261-5267.

Wells, M. L., Gitaitis, R. D., and Sanders, F. H. 2002. Association of tobacco thrips, Frankliniella fusca (Thysanoptera: Thripidae) with two species of bacteria of the genus Pantoea. Ann. Entomol. Soc. Am. 95:719-723.

Wu, S., Peiffer, M., Luthe, D. S., and Felton, G. W. 2012. ATP hydrolyzing salivary enzymes of caterpillars suppress plant defenses. PLoS One 7: e41947.

Zhou, C., Walker, M. J., Williamson, A. J. K., Pierce, A., Berzuini, C., Dive, C., and Whetton, A. D. 2014. A hierarchical statistical modeling approach to analyze proteomic isobaric tag for relative and absolute quantitation data. Bioinformatics 30:549-558.

Zhu, F., Poelman, E., and Dicke, M. 2014. Insect herbivore-associated organisms affect plant responses to herbivory. New Phytol. 204:315-321.

\section{AUTHOR-RECOMMENDED INTERNET RESOURCES}

The Lepidoptera Taxome Project website: http://www.ucl.ac.uk/taxome National Center for Biotechnology Information website: http://ncbi.nlm.nih.gov

Ribosomal Database Project website: http://rdp.cme.msu.edu 